THE HITTITE SEAPORT IZZIYA at Late Bronze Age Kinet Höyük (Cilicia)

Author(s): Marie-Henriette Gates

Source: Near Eastern Archaeology, Vol. 76, No. 4 (December 2013), pp. 223-234

Published by: The American Schools of Oriental Research

Stable URL: https://www.jstor.org/stable/10.5615/neareastarch.76.4.0223

JSTOR is a not-for-profit service that helps scholars, researchers, and students discover, use, and build upon a wide range of content in a trusted digital archive. We use information technology and tools to increase productivity and facilitate new forms of scholarship. For more information about JSTOR, please contact support@jstor.org.

Your use of the JSTOR archive indicates your acceptance of the Terms \& Conditions of Use, available at https://about.jstor.org/terms 


\section{THE HITTITE SEAPORT IZZIYA at Late Bronze Age Kinet Höyük (Cilicia)}

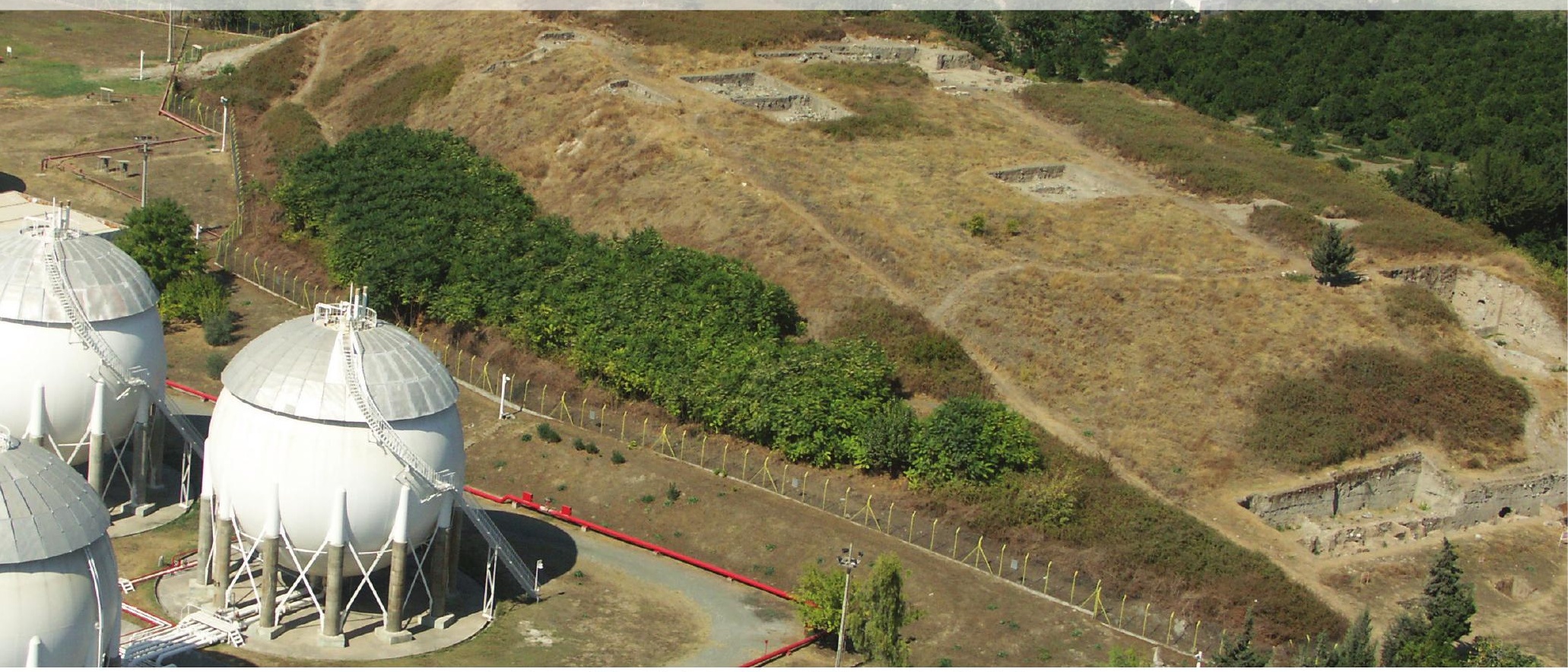

Aerial view of Kinet Höyük from the south. Photograph by M.-H. Gates.

\section{Marie-Henriette Gates}

$L$ ocation would predict a modest role in antiquity to the small seaside mound of Kinet Höyük, on the eastern limits of classical Cilicia in southern Turkey (fig. 1). The site sits hidden in the northeasternmost corner of the Mediterranean at the back of Iskenderun Bay, outside the attention of major shipping routes. Roads between Anatolia and Syria would also have skirted the narrow coastal plain behind Kinet Höyük to avoid the steep Amanus mountains on the east and north. This barrier discouraged overland transit, redirecting it to the interior through the Islahiye Valley that links modern Gaziantep to the Amuq, and southeastern Anatolia with western Syria. Such is the impression that maps and topography convey about the site's status and connectivity.

Kinet Höyük's archaeological prospects seemed more attractive, however, and did invite attention. Surveys in the last century recorded a long occupational sequence from prehistoric times to the Crusader era, and little disturbance since then. The site promised insights on how a small port maintained and adapted its livelihood over a span of several thousand years. It also presented to excavators the prospect of documenting a region whose nearest excavated sites - all projects of the 1930s-40s were $175 \mathrm{~km}$ to the west at Tarsus, and $100 \mathrm{~km}$ to the south in the Amuq. Additionally, not a single Bronze Age seaport had been investigated on Turkey's entire Mediterranean coast.
Issues like these shaped the initial aims of Bilkent University's excavations at Kinet Höyük, which started in 1992 after a brief survey the previous year. There was also some urgency, caused by threats to the mound by its immediate neighbor, an oil and gas shipping facility whose business fortunes were tied to the oil pipeline that runs from Mosul in northern Iraq to terminals at this end of Iskenderun Bay (fig. 2). The recent patterns of commercial boat traffic into the back of the bay, precisely where Kinet Höyük was situated, alerted us to its current maritime advantages. It remained for the project, over the course of twenty seasons (1992-2012), to determine what circumstances shaped this small seaport in the past. It also faced the challenge of explaining why this modest place invited the interests of major historical players. These included the Hittite state, which brought the site under its cultural influence ca. 1500 B.C.E. in Late Bronze I (LB I), and maintained its dominance over the seaport for the next three centuries.

\section{A Well-Connected Middle Bronze Age Seaport}

Kinet Höyük's physical setting must have been instrumental in attracting Hittite attention. Its merits cannot be understood from the archaeological criteria for land-based sites, where hectares equate with rank (fig. 3). They instead responded to the needs of boats as well as variables based on coastlines, climate, currents, 


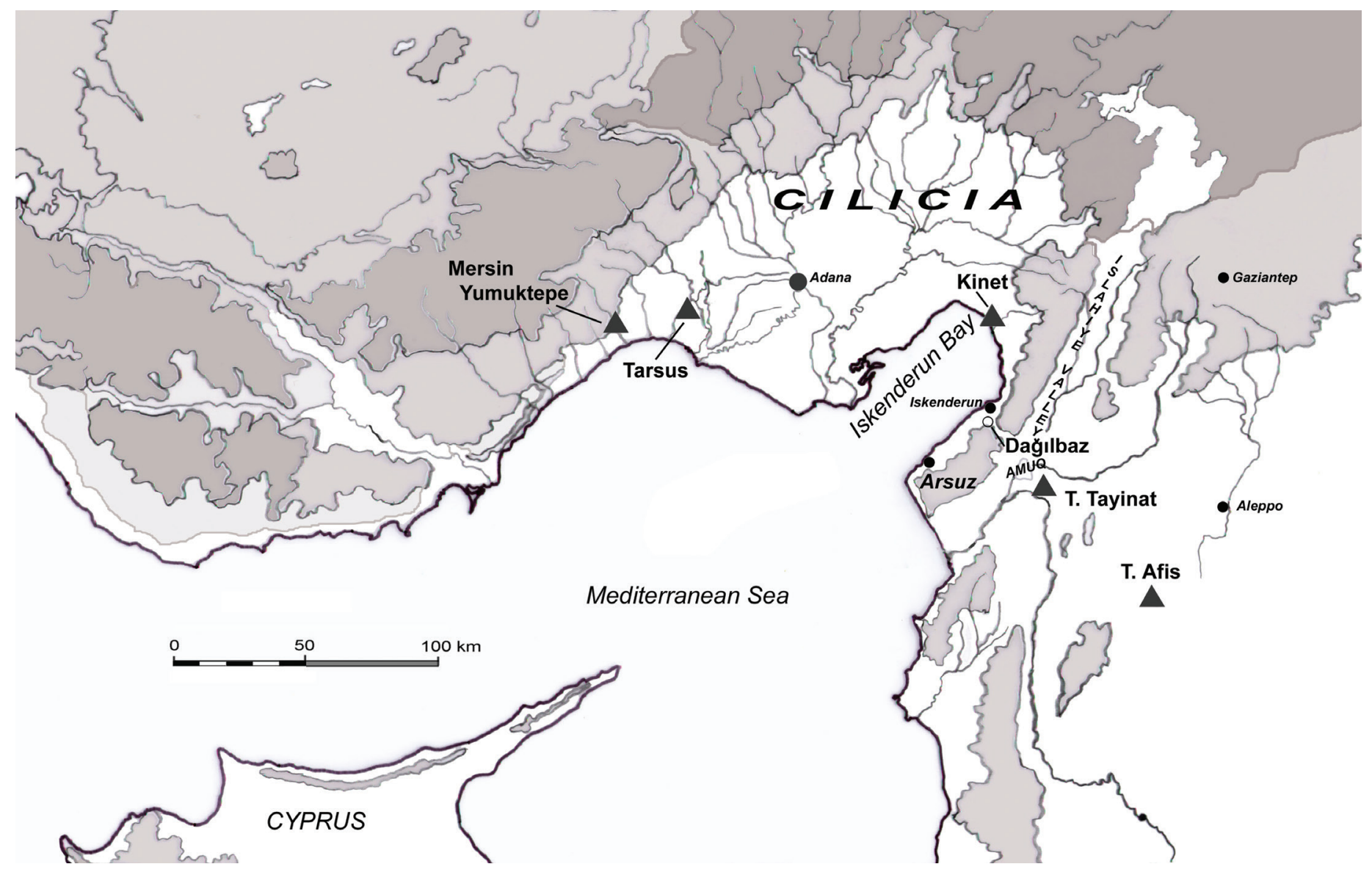

Figure 1. Map of Cilicia and the northeastern Mediterranean, with sites mentioned in the text. Map by M.-H. Gates.

and seasons. By the Early Bronze Age, when the mound reached its modest maximum of 3.3 ha., it had achieved enough height to be visible from the plain, the surrounding hills, and the sea. It was configured like the promontory it resembles today: broad and straight on its inland/east side, pointing west towards the sea, ca. $525 \mathrm{~m}$ distant (fig. 4). Soundings in the fields north of the mound found structures scattered along the seaside throughout the mound's settlement periods. Until the first century B.C.E., a river estuary on the mound's south flank and a shallow bay to the north supplied Kinet Höyük with suitable harbors (Beach

Figure 2. Kinet Höyük and the back of Iskenderun Bay from the southeast; the mound is in the lower right, behind the LPG tanks. Aerial photograph by M.-H. Gates (2004).

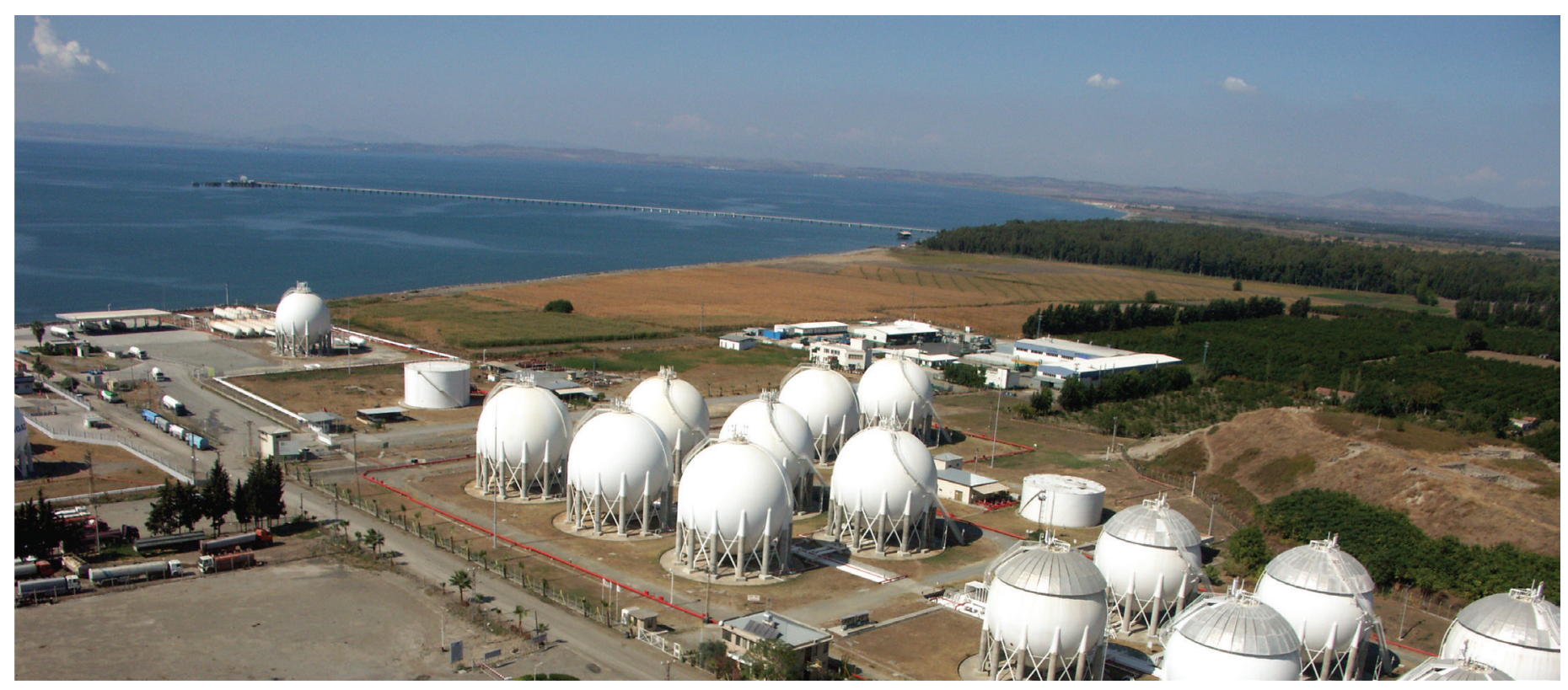


and Luzadder-Beach 2008: 419). One crucial factor determined Kinet Höyük's appeal and longevity: winds do not reach the back of this bay. It therefore offered exceptional shelter to boats in antiquity, as it does to the oil and gas tankers that dock beside Kinet Höyük today.

Kinet Höyük's development in the centuries preceding the Hittite state also designated the port for its later exploitation. At the start of the second millennium (MB I), Kinet Höyük was culturally aligned with Cilicia, its ceramic repertoire and other finds forming a circumscribed regional assemblage with Tarsus and Mersin. Like them, Kinet Höyük was drawn into

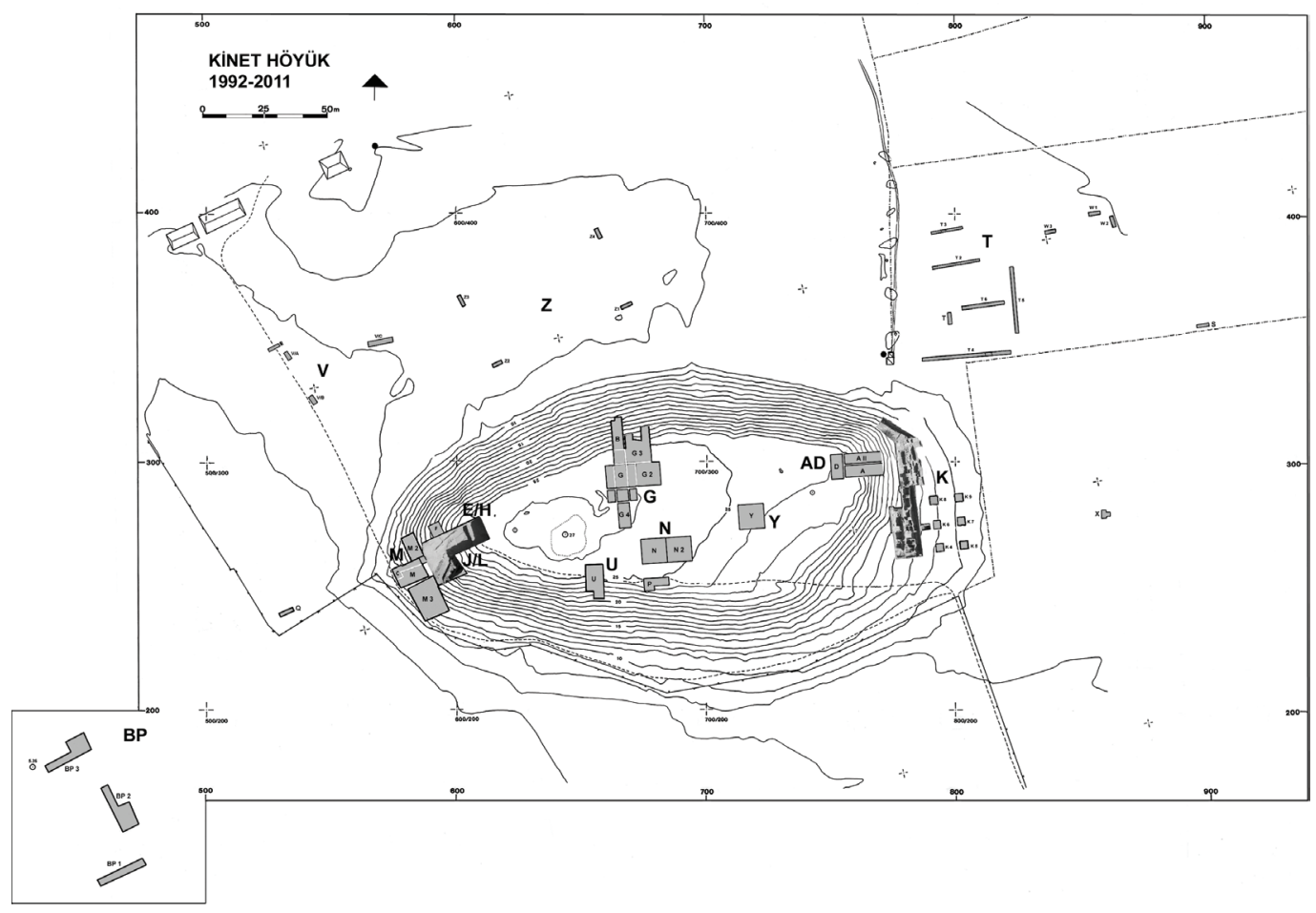

Figure 3 (above). Topographical plan of Kinet Höyük. Courtesy of Kinet Höyük archives.

Figure 4 (below). View of Kinet Höyük from the northwest. The Late Bronze operations on the West Slope are on the lower right; the Middle Bronze operations in Area K at the far left. The sea is $525 \mathrm{~m}$ to the right. Balloon photograph by E. Küçük, Airstudyo (2010)

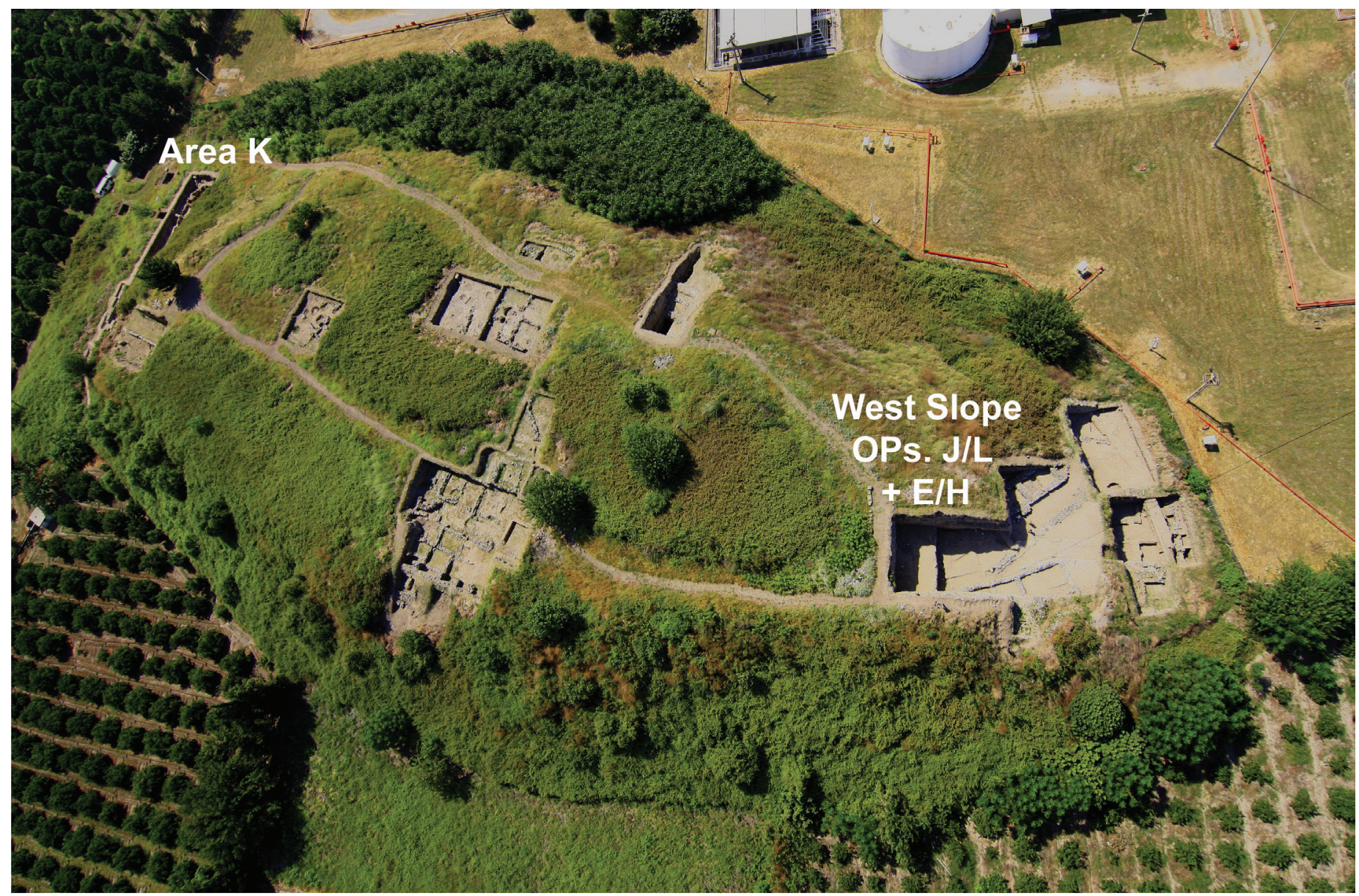


the maritime commercial network that emerged along the eastern Mediterranean coast at the start of MB II (eighteenth century B.C.E.) under Hyksos promotion from the eastern Nile Delta and with Canaanite entrepreneurship (Muhly 2005; Knapp 2012: 418-19). It is at this moment that Cyprus, this region, and Kinet

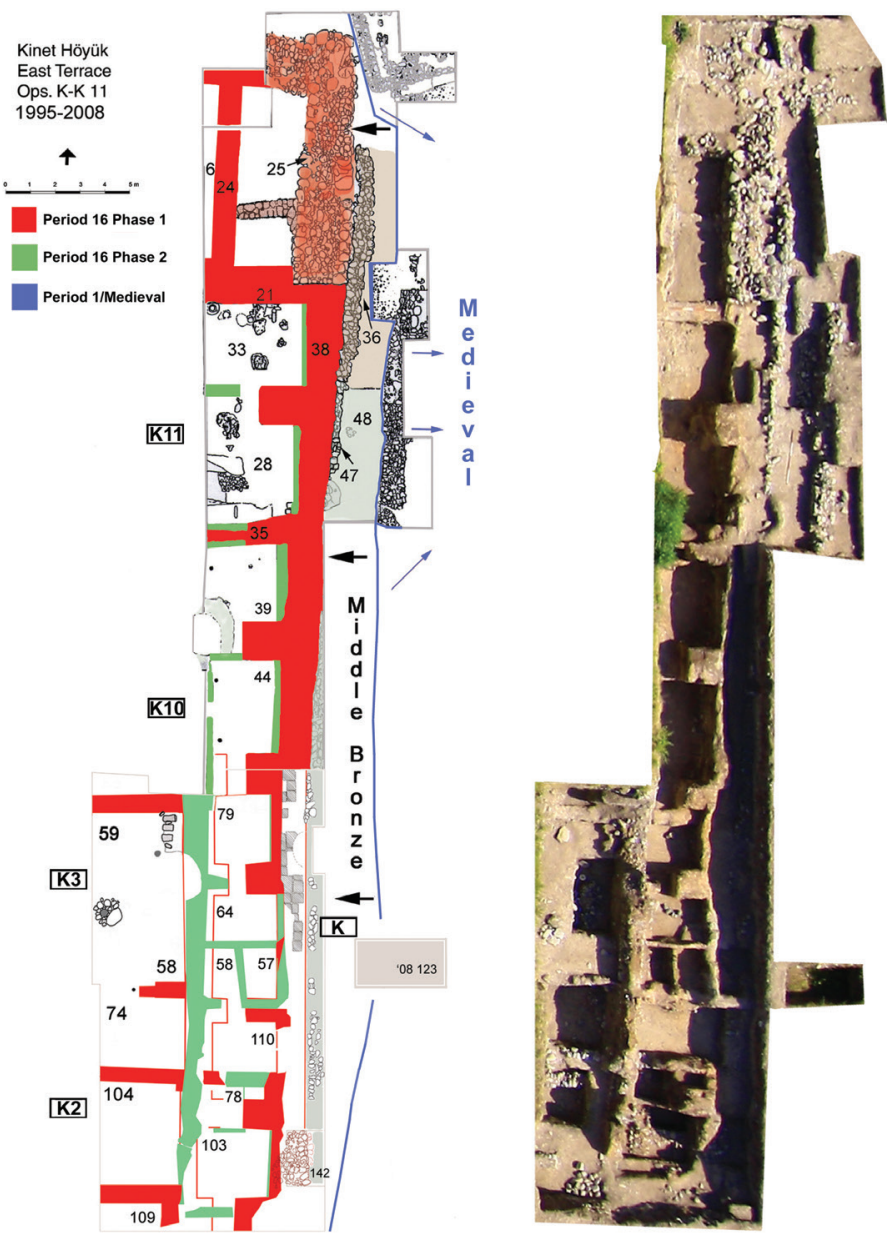

Figure 5. Kinet Höyük Area K's Middle Bronze II/III (Period 16) building in plan (left), and in balloon photograph by E. Küçük, Airstudyo (2010) (right).

Höyük's archaeological record first showed sustained connections with the world outside their immediate borders.

Middle Bronze deposits at Kinet Höyük were sampled in limited exposures on the mound's west, seaside slope (1993 OP. C and the upper phases of 1995 OP. M). They were especially accessible on the mound's inland side in Area $\mathrm{K}$, where they lie close to the modern surface. Excavations here from 1995 to 2004 recovered ca. $365 \mathrm{~m}^{2}$ of a single Middle Bronze structure: a building whose mudbrick walls, destroyed by fire, were preserved up to heights of $2 \mathrm{~m}$ (fig. 5). This sector represents the building's east wing and heavy outer wall, which was followed for nearly $50 \mathrm{~m}$ to the building's massive northeast corner. Soundings to the building's east and north determined that it stood at the very edge of the Middle Bronze mound's eastern and northern slopes, rising like ramparts twelve or more meters above the plain. The impressive exterior and the placement identify the building as a fortress, whose squared plan belonged to the MB II tradition of
Levantine military architecture. Its presence at this small seaport is unexpected, a sign that Kinet Höyük's stature was already disproportionate to its size.

Furnishings, stratigraphy, and radiocarbon samples date this level, Kinet Höyük Period 16, to late MB II and MB III: the build-

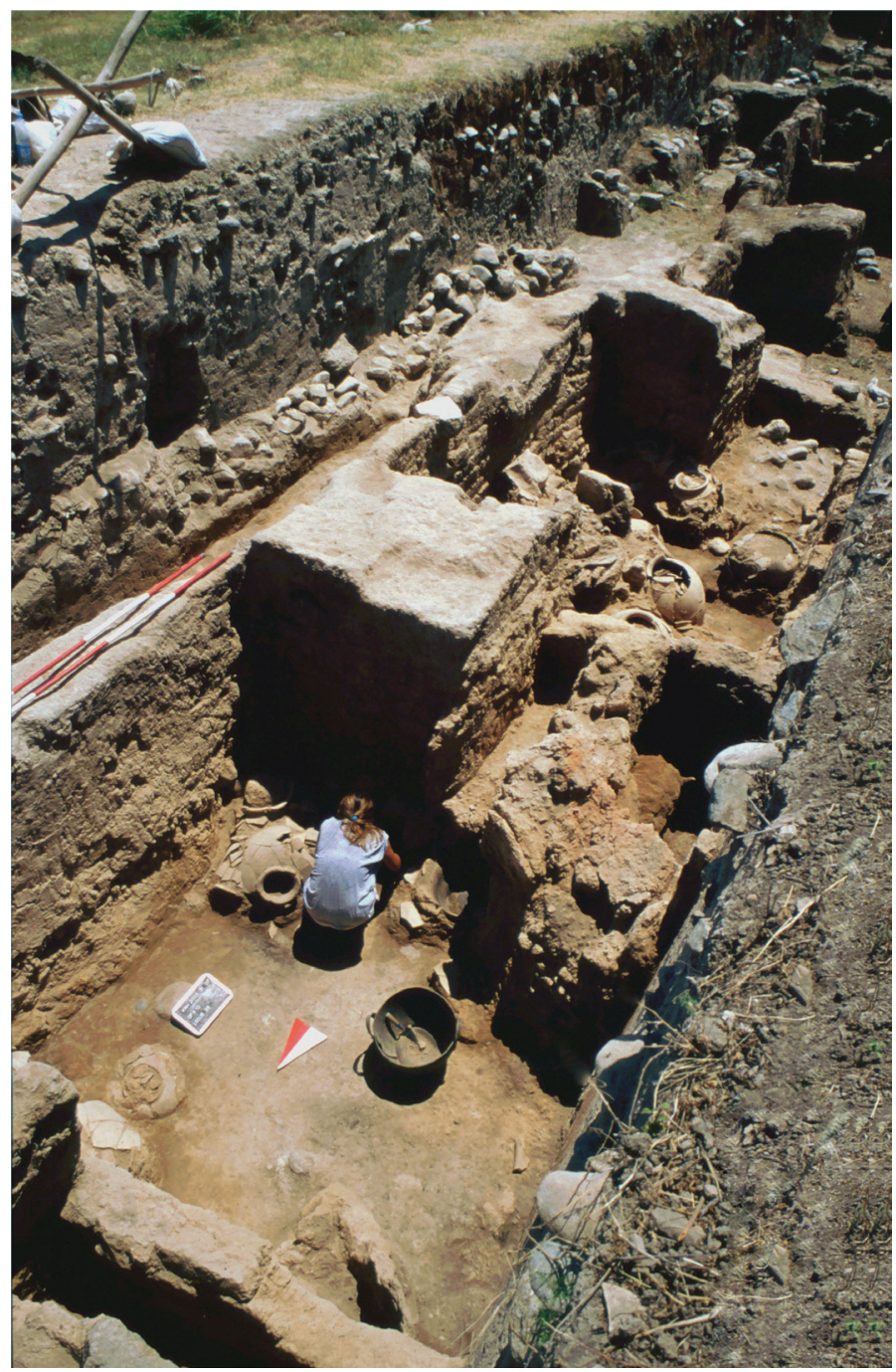

Figure 6. Kinet Höyük Area K's Middle Bronze II/III (Period 16) building at the end of the 2003 season. In the foreground, Op. (trench) K10 and supervisor Ayşe Tuğcu in its northern store room; to the south are Ops. K and K2, excavated in 1995, 1998, and 1999. Photograph by M.-H. Gates.

ing's construction, two phases and destruction spanned the late eighteenth to mid-sixteenth centuries B.C.E. ${ }^{1}$ Its east wing housed three workshops equipped with furnaces and hearths, and fourteen storerooms. Their several hundred jars, cooking pots, utilitarian vessels and tablewares convey the building's formal nature and activities (Gates 2011: 184-7) (fig. 6). Its ceramic assemblage fits the eastern Mediterranean manufacturing traditions from Palestine to western Syria (fig. 7). By the sixteenth century B.C.E., their regional painted traditions merged into a style produced everywhere by local workshops. The Period 16 building's many Cilician/Syro-Cilician Painted Ware drinking sets illustrate this fashion: craters, pitchers, and cups decorated with monochrome and bichrome geometric patterns (fig. 7, upper left). The 
maritime commerce that promoted these exchanges and Kinet Höyük's participation in them are indicated by two other classes of MB II and MB III pottery: prototypes of the Canaanite Jar, the first container designed for transport by boat (fig. 7, right), and the earliest Cypriot export wares (fig. 8, lower right). ${ }^{2}$ By the time the Hittite Old Kingdom fixed its ambitions on the Mediterranean's international shipping routes, the seaport at Kinet Höyük was a well-frequented stop on the coastal highway.
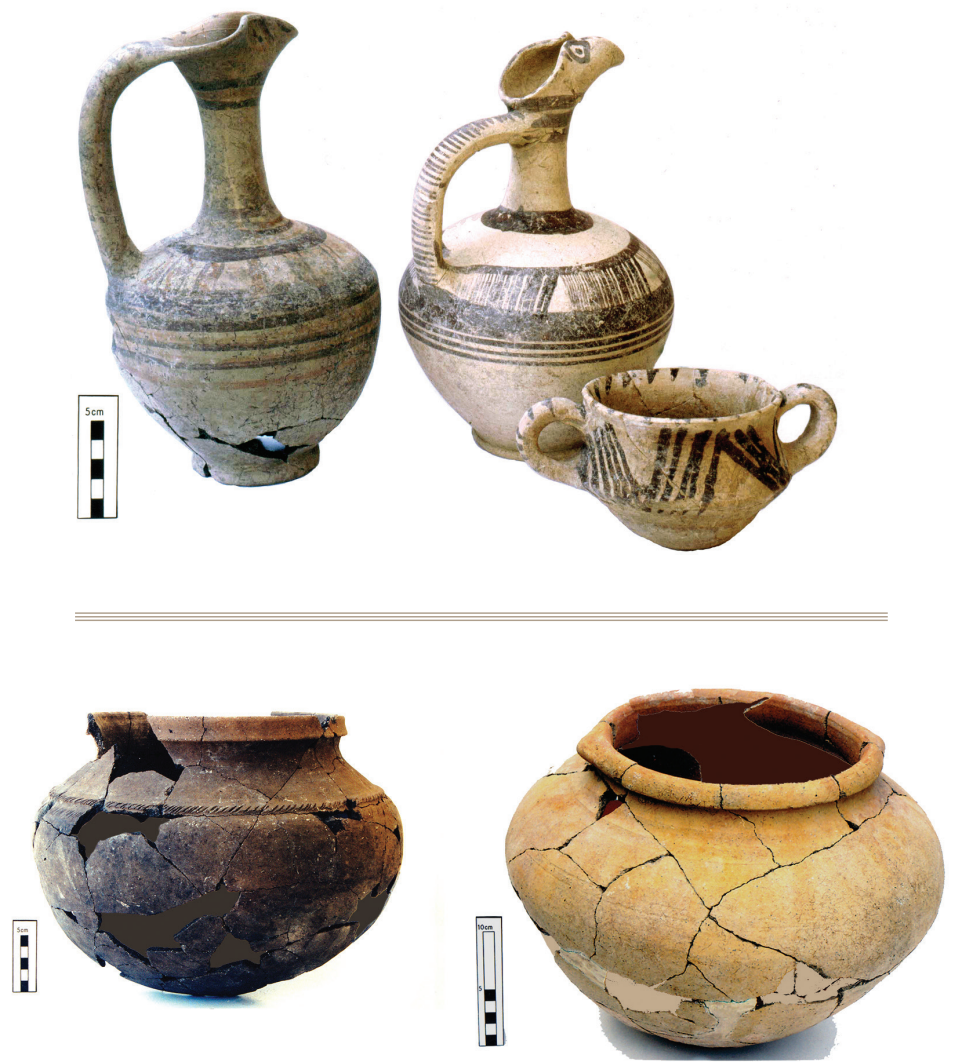

Figure 7 (above). Typical local ceramic vessels from Kinet Höyük Area K's Middle Bronze II/III (Period 16) building: Cilician Painted ware pitchers and cup (upper left); cooking pots (lower left); and Canaanite jars (upper and lower right). The jar on the upper right has a potmark incised above one handle.

Figure 8 (below). A selection of Cypriot pottery imports from Kinet Höyük. The two Bichrome sherds (lower right) are from Area K's Period 16 building; the Base Ring I juglet (left) and White Slip II milkbowl fragment (upper right) from the West Slope's Late Bronze II (Period 14) street in 2007 OP. E/H. Photographs by T. Çakar and M.-H. Gates.
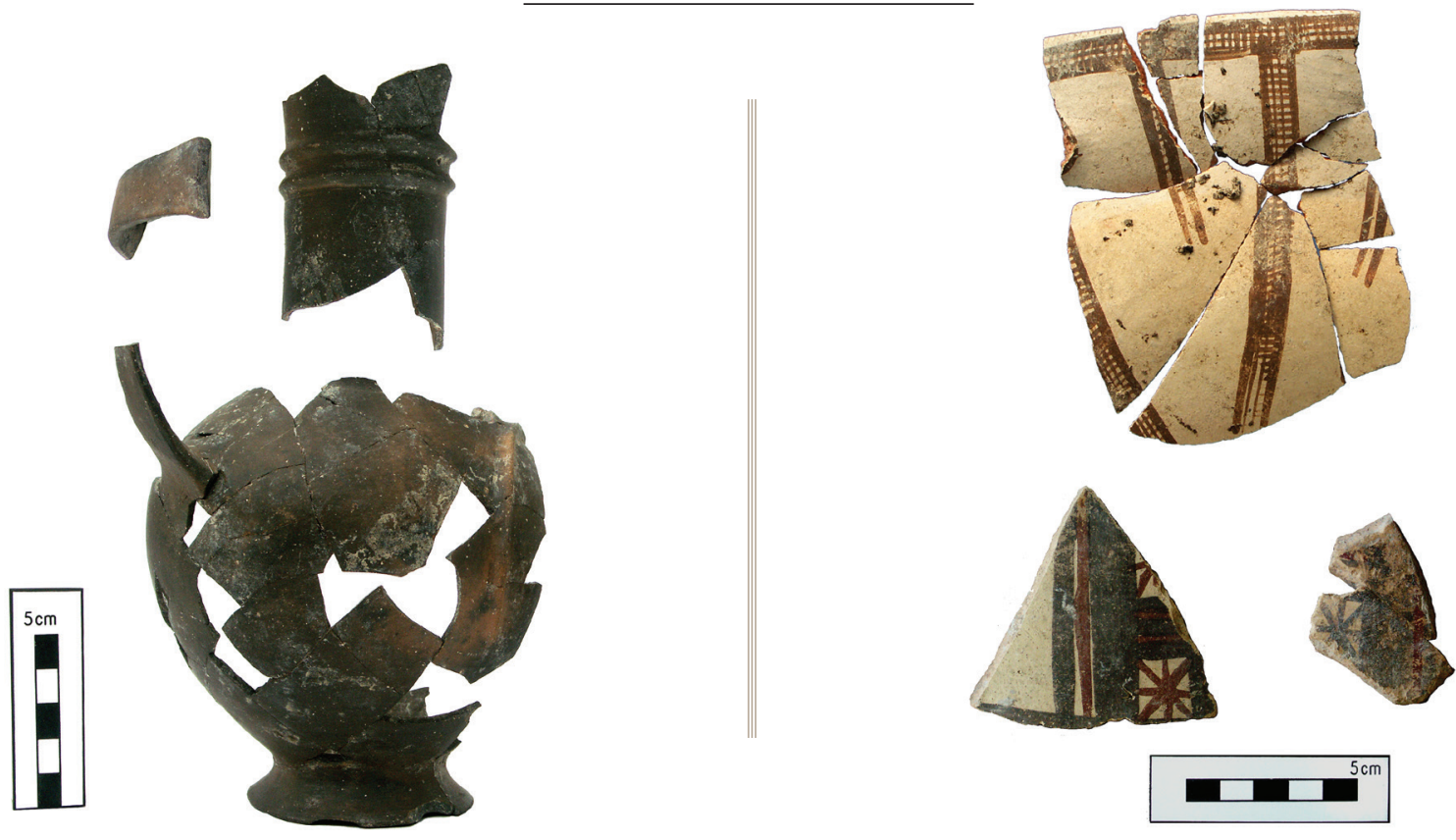


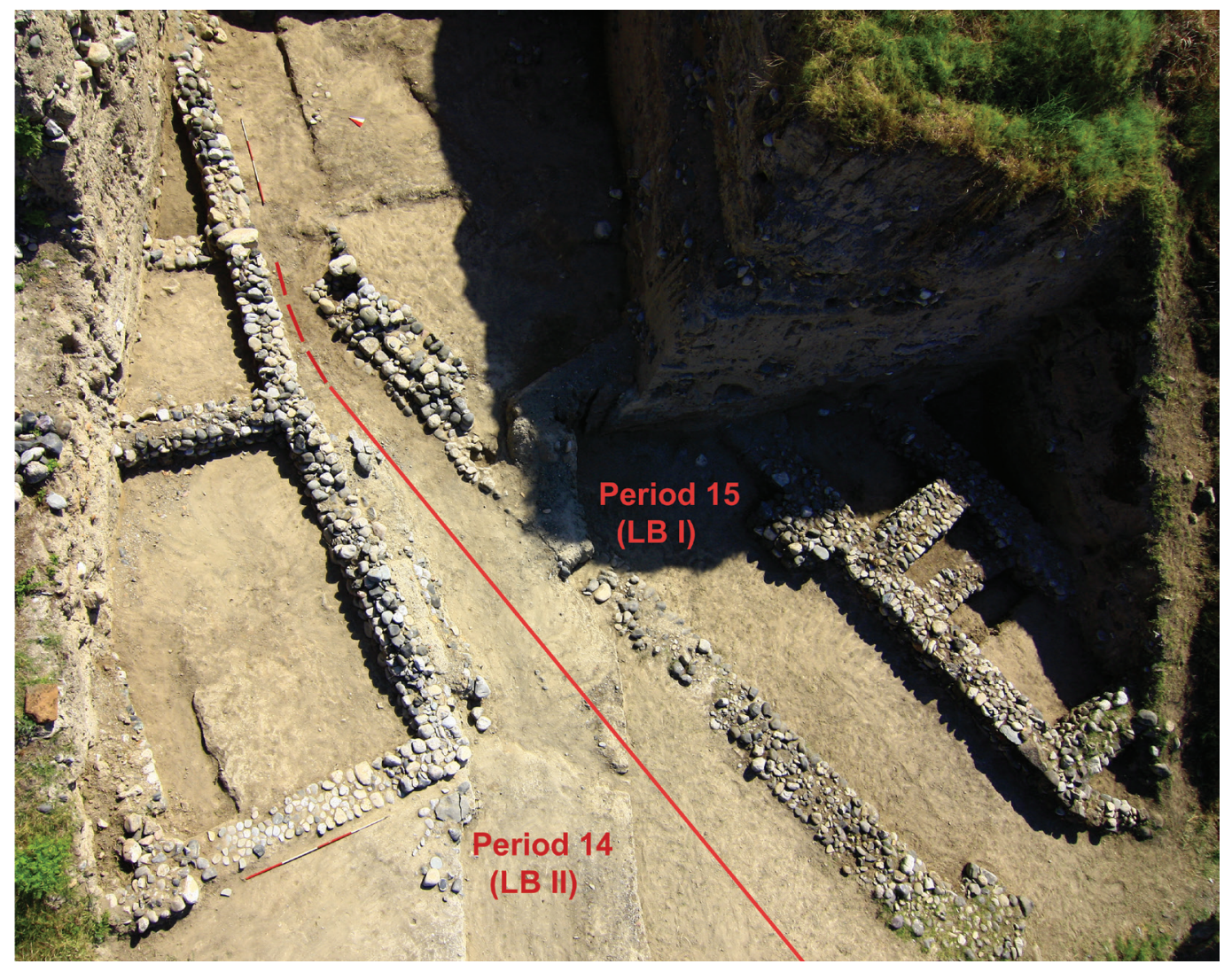

tion to brick superstructure. Period 15 is represented by three phases of one building: a $21 \mathrm{~m}$ stretch of façade with a stepped threshold and porch, and two parallel units of rooms (figs. 10 and 11). The compartmental layout and absence of doorways at foundation level recall Hittite architecture, but additional features may be hidden in the unexcavated parts and thus, this small exposure may be misleading. Period 14 replaced it in LB II with another large structure and a domestic building, separated by a gravelled street rich in household trash (fig. 12). The fires that destroyed this level and its Period 13.1 successor preserved in situ furnishings of strikingly Hittite derivation, a distinctive material

Figure 9 (above). Kinet Höyük's Late Bronze Periods 15 and 14 in the combined West Slope operations $\mathrm{J} / \mathrm{L}$ and $\mathrm{E} / \mathrm{H}$, at the end of the 2007 season. Balloon photograph by E. Küçük, Airstudyo (2010).

Figure 10 (below). The earliest Hittite presence on Kinet Höyük's West Slope: plan of the Late Bronze I (Period 15) building in Ops. J/L - E/H.

\section{Late Bronze Age Kinet Höyük under Hittite Management}

Kinet Höyük's physical remodelling into a Hittite settlement was sudden and visually expressive. ${ }^{3}$ Large-scale construction faced the sea on the mound's west side, where it was exposed over ca. 280 $\mathrm{m}^{2}$ in OP. J/L (1994-98) and adjacent OP. E/H (2005-07) (fig. 9). Kinet Höyük Period 15, the first Hittite level (LB I), broke with Middle Bronze orientation and pivoted walls towards the northeast. Masonry techniques were different: small blocks from volcanic beds $15 \mathrm{~km}$ away combined with the usual local river stones for wall foundations; and a course of wood headers, held by a thick mud mortar, stabilized the transition from stone founda-

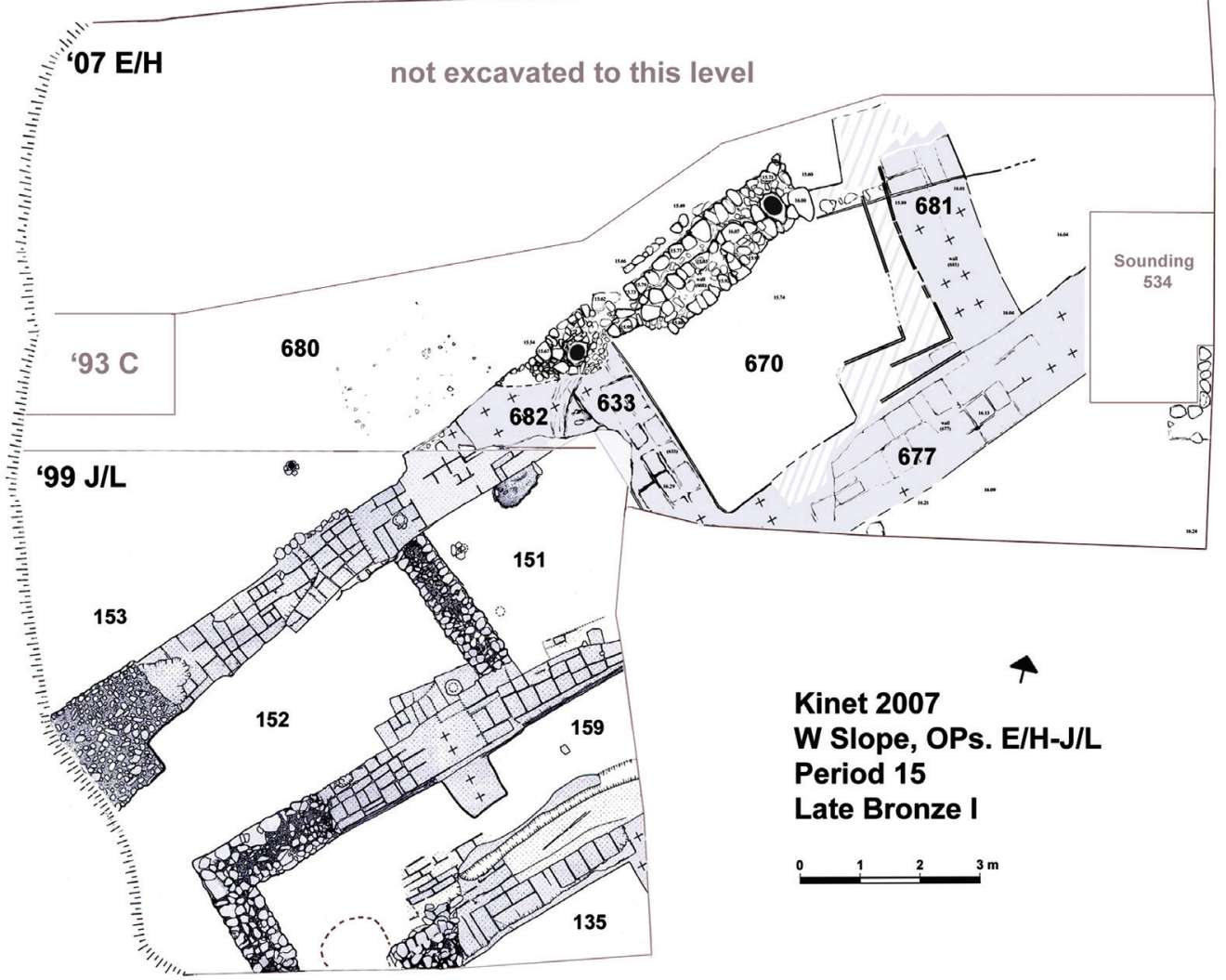


culture introduced in Period 15 (fig. 13).

The ceramic assemblage that accompanied Kinet Höyük's Period 15 installations assumed the technical, formal, and functional characteristics of a Central Anatolian industry and tradition. Hittite potters narrowed their Late Bronze output to a few sturdy fabrics and plain finishes and a limited range of plates, bowls, craters, flasks and pitchers, storage jars, and cooking vessels. Their manufacturing standards were upheld with surprising uniformity throughout Hittite territory until the demise of their empire in the twelfth century B.C.E. (Schoop 2003: 171-75; 2011: 264-265).

At Kinet Höyük, this repertoire wiped out every trace

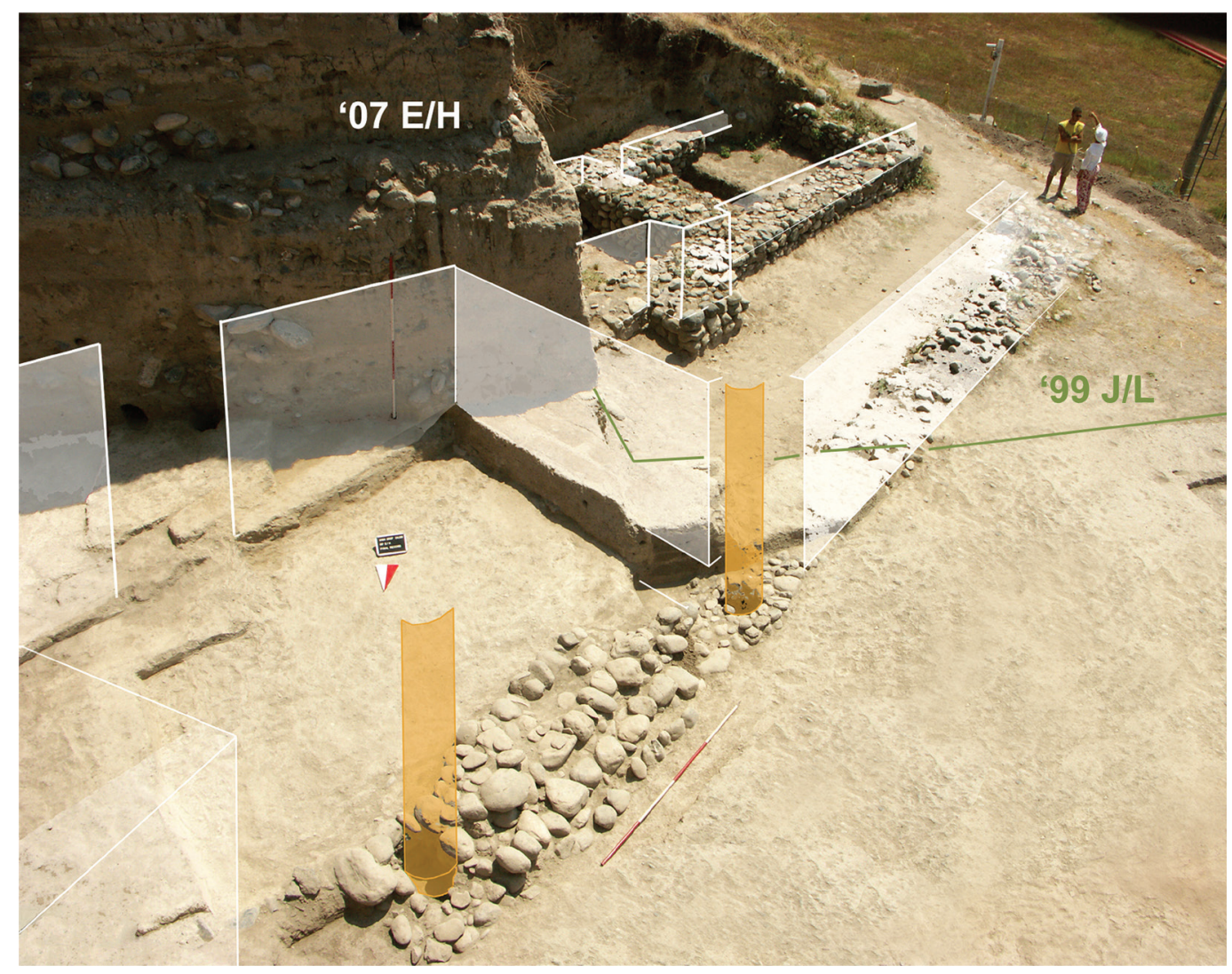

Figure 11 (above). The earliest Hittite presence on Kinet Höyük's West Slope: the Late Bronze I (Period 15) building in Ops. J/L - E/H, viewed from the north. In the foreground, three steps framed by two posts lead into the building. Photograph by M.-H. Gates, with enhancements.

Figure 12 (below). Plan of the Late Bronze II (Period 14) level that replaced the first Hittite installation. A large building to the north, another to its southwest, and the gravelled street between them saw several phases of use, accounting for at least a century.

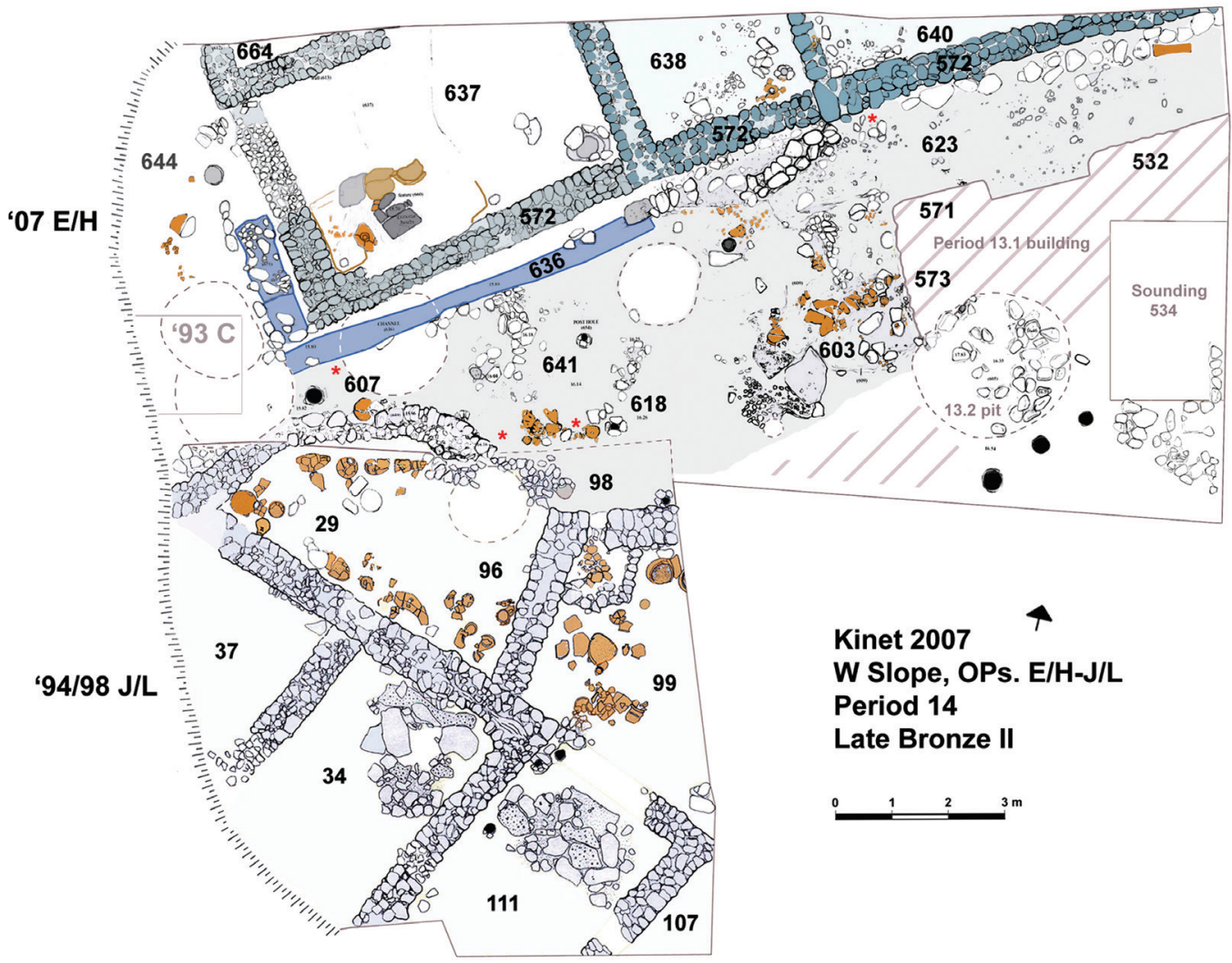

of the Middle Bronze Age serving vessel, tableware, and painted drinking set, and replaced them with Hittite dining conventions (fig. 14). We see that cooking methods from the Anatolian plateau were adopted, substituting baking or roasting platters in ovens for the Middle Bronze casseroles on open hearths. Kinet Höyük's potters also adhered to Hittite industrial practice by incising potmarks on their products before firing them in the kiln (fig. 14, left). The only exceptions to this pattern applied to local business equipment: the Late Bronze descendants of $\mathrm{Ca}$ naanite jars (fig. 15). But their handles could now bear Hittite stamps, like two examples from LB II Kinet Höyük (fig. 16), and a third from nearby Dağılbaz, above Iskenderun 


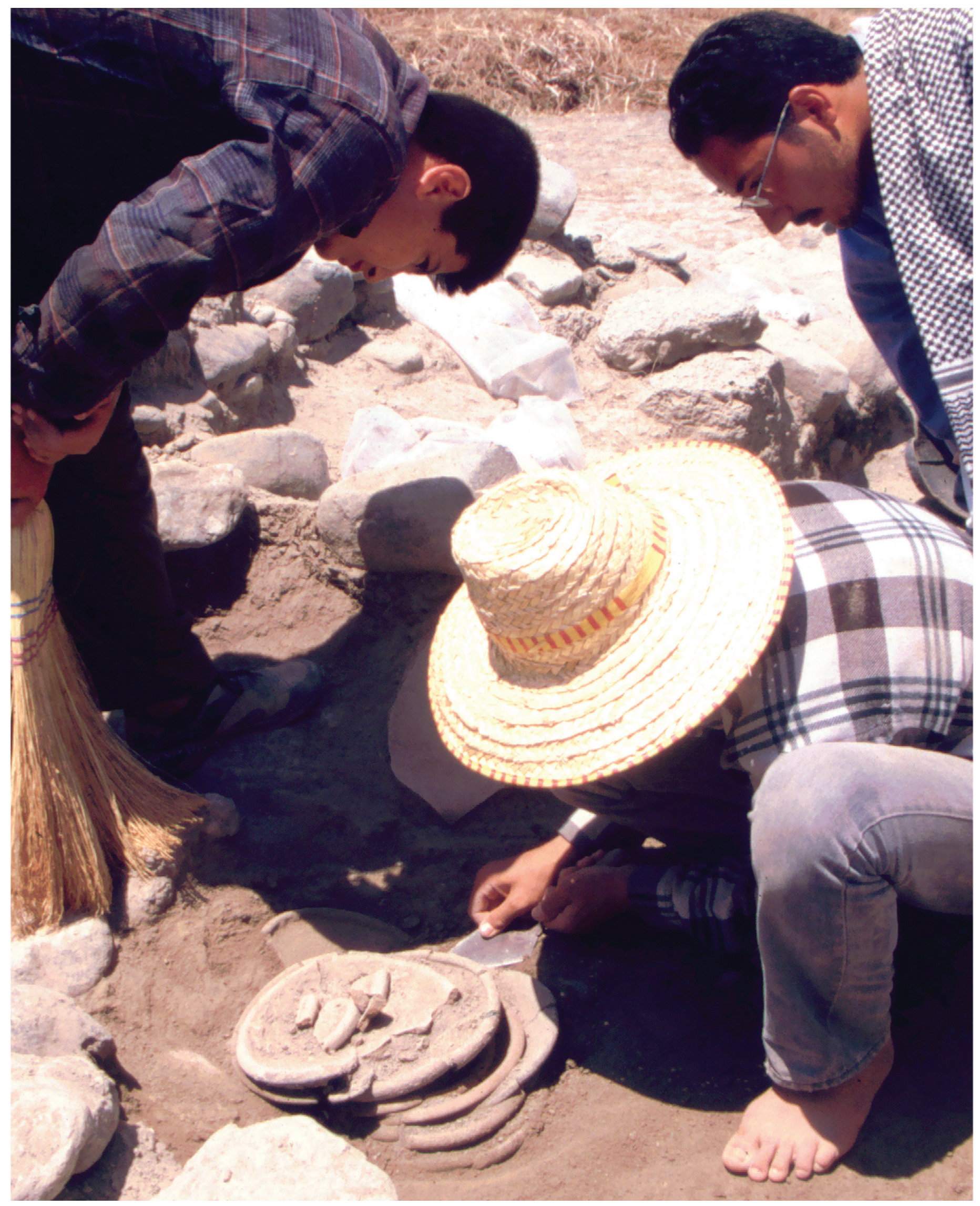

Figure 13. LB II pottery on the floor of the burnt Period 14 store room 29+96, excavated in OP. J/L in 1998 by Emre Şerifoğlu. Photograph by M.-H. Gates. 

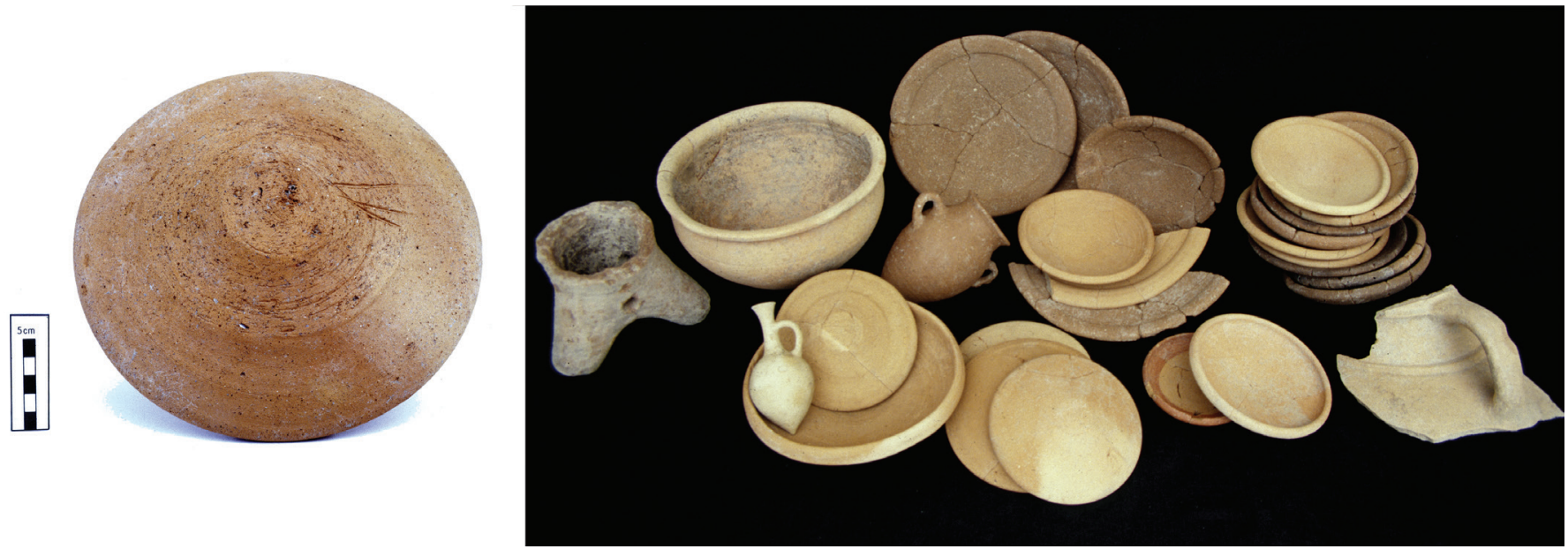

Figure 14 (above). Typically Hittite table ware and kitchen equipment from the burnt Late Bronze II (Period 14) store room $29+96$ and kitchen 99 in 1998 OP. J/L. Two coarse baking platters stand upright at the center back; on the left, a potmark incised on the outer face of a bowl with incurved rim.

Figure 15 (below). A Late Bronze II (Period 14) Canaanite jar from kitchen 99 in 1998 OP. J/L; height $=65 \mathrm{~cm}$, maximum diameter $=43 \mathrm{~cm}$

Photographs by T. Çakar; illustration by N. Yılmaz.
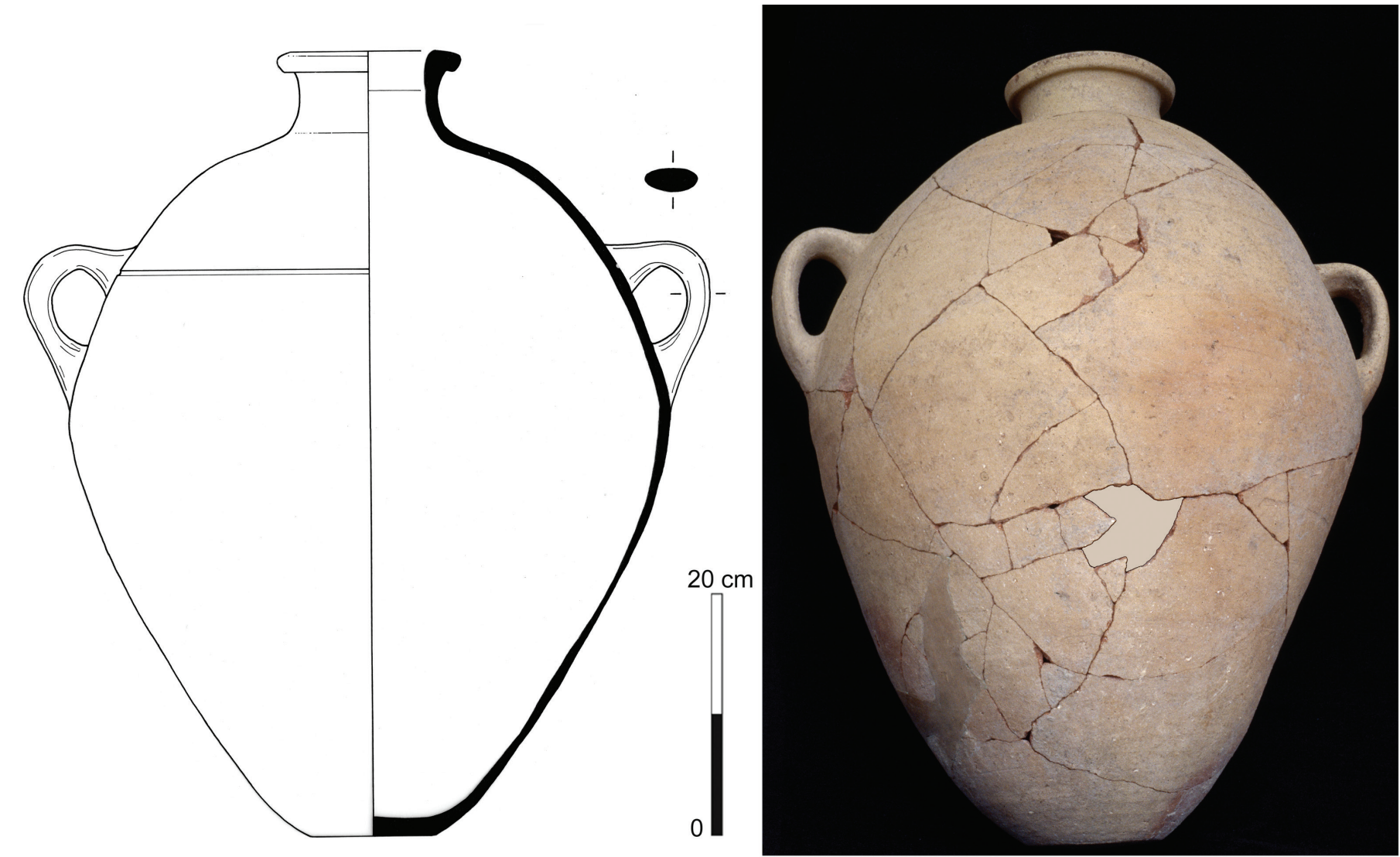


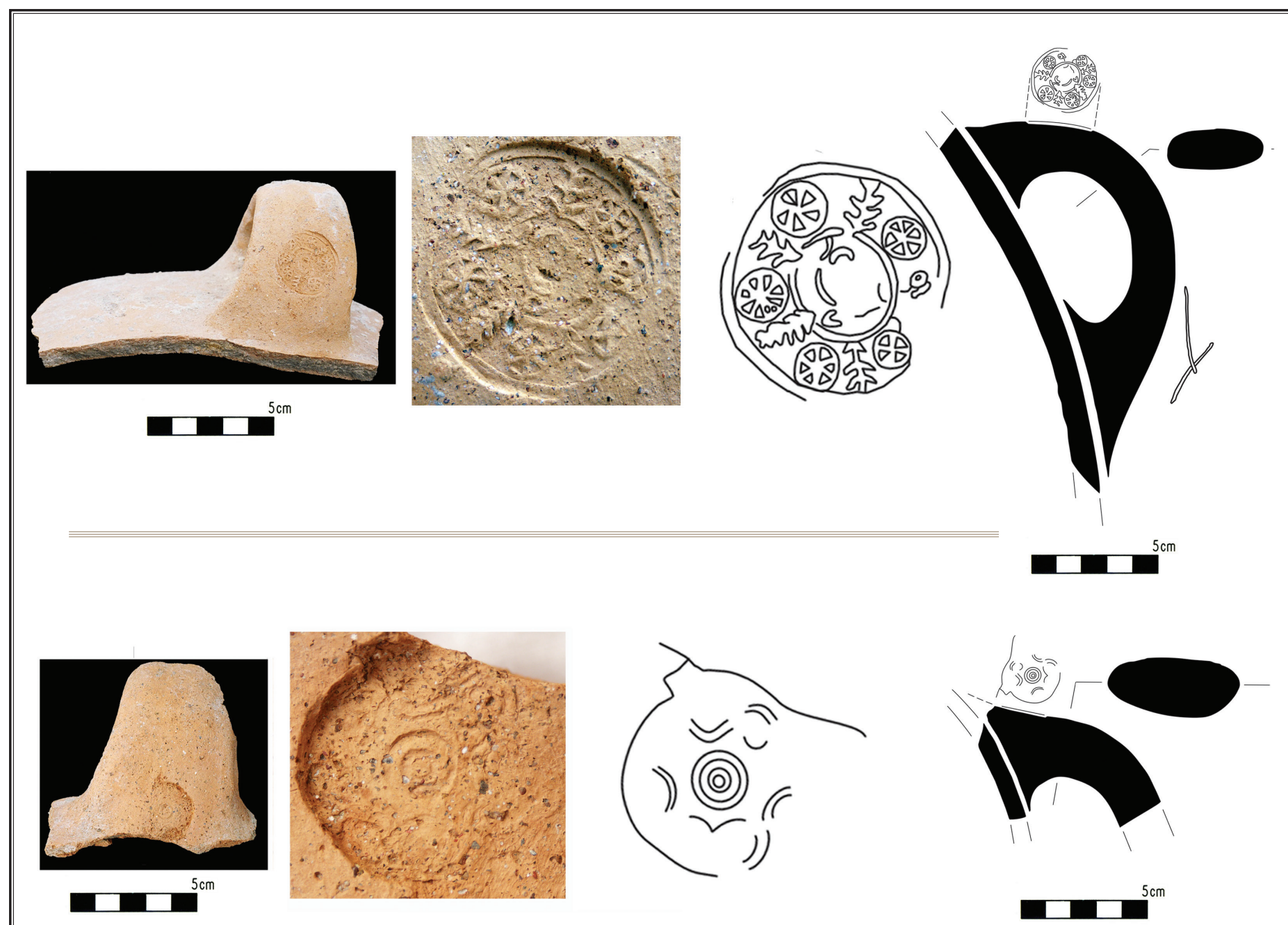

Figure 16. Late Bronze II (Period 13.1) Canaanite jar handles stamped with Hittite seals, from 2006 OP. E/H. Illustrations by F. Yılmaz, photographs by M.-H. Gates.

(D’Alfonzo and Killebrew 2011). That other aspects of Hittite culture permeated this seaport may be indicated by the head and horn of two bull figurines and a fragmentary vessel in the shape of a bird of prey (fig. 17); their red- and brown-burnished fabrics and distinctive forms are typical of Hittite cult objects. It is not possible to speculate on the population and ethnicity of Late Bronze Age Kinet Höyük, however, without explicit textual evidence.

\section{Kinet Höyük in History and Texts: Issos, Sissu, and Izziya/Zise}

By the nineteenth century C.E., historical consensus had situated the classical seaport Issos, near the battlefield where Alexander the Great defeated Darius III Codommanus in 333 B.C.E., at Kinet Höyük. No other site in the region answered the descriptions by Xenophon and other ancient witnesses about location, harbor facilities, and antiquity. Philological arguments then drew up antecedents for this place-name: Late Iron Age Sissu, a target of the Assyrian king Esarhaddon (680-69 B.C.E.); LB II Izziya, where
Hittite Queen Puduhepa performed seaside rites six hundred years earlier; and LB I Zise, a Hittite city conquered by Idrimi of Alalakh in the early fifteenth century B.C.E. ${ }^{4}$ The newest reference to Izziya, in a Hittite letter discovered at Tell Afis five years ago, gives travel times that strengthen its connection with Kinet Höyük (Archi and Venturi 2012: 34-8, 45-7).

These identifications remain circumstantial since the Kinet Höyük excavations did not produce written records that name it. The archaeological sequence, on the other hand, coincides in all points with their historical contexts. Kinet Höyük's Late Bronze Age levels document a Hittite cultural presence from the time of Idrimi to Puduhepa and beyond, making the attribution of a Hittite name a reasonable possibility. Its LB I profile shows why Idrimi could refer to Zise and its neighbors as Hittite cities, a century or more before the region's formal annexation. Kinet Höyük especially illustrates the pervasiveness of Hittite standards in material culture, and, by extension, statehood.

Their deep roots may explain the formalities that were upheld by western Syria's later Aramaean ("Neo-Hittite") states: royal 

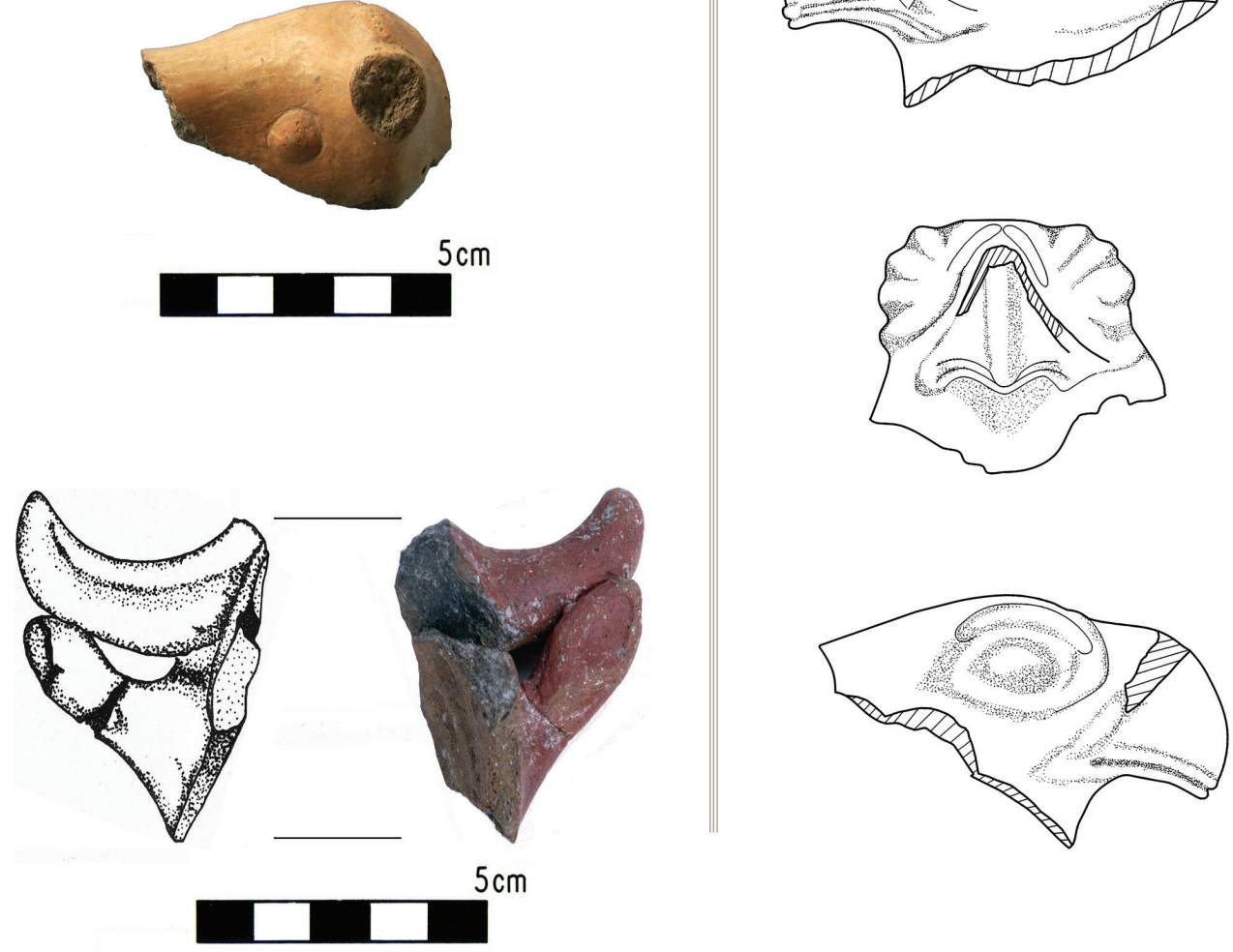
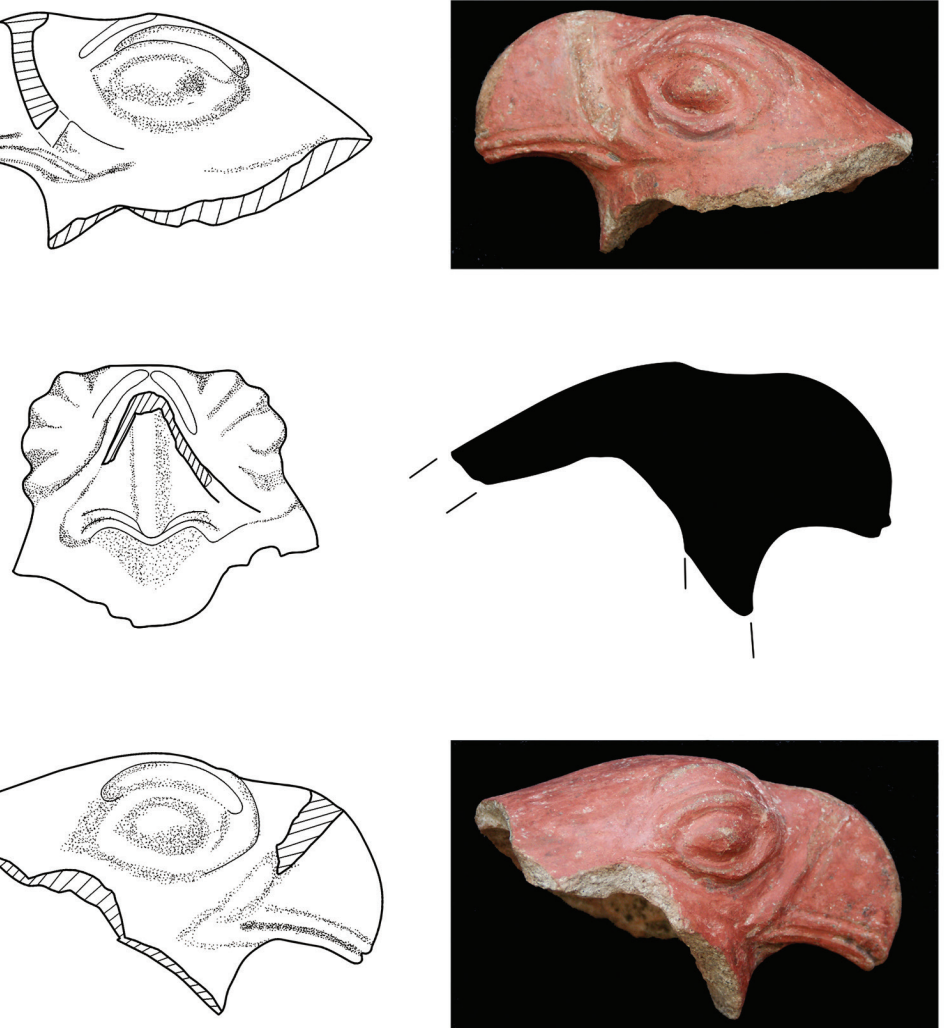

Figure 17. Fragments of two bull figurines (left) and a zoomorphic vessel with a bird of prey (right), from Late Bronze II (Period 14) Kinet Höyük. Illustrations by N. Yılmaz and F. Yılmaz; photographs by T. Çakar and M.-H. Gates.

names, titles, and official Hieroglyphic Luwian script. Two stelae, found in 2007 south of Iskenderun at Arsuz, proclaim the territorial conquests of a ninth-century "Suppiluliuma, Hero," who came to rule Patina/Unqi in the Amuq, campaigned as far as Cilicia, and destroyed Adana (Dinçol and Dinçol). Suppiluliuma's - or a namesake's - inscribed statue was discovered during the 2012 excavations at his capital Kunulua, modern Tell Tayinat. ${ }^{5}$ His name and title invoke the Hittite empire's founder; and he wrested his throne from a ruler named Lubarna, a venerated title from earliest Hittite kingship. These local chiefs declared their lineage not to Hittite dynastic succession, but to an administrative system and regal ideology inherited from the Hittite state. To the Assyrians who encountered them, and perhaps even to themselves, these latter-day Suppiluliumas and Lubarnas were the true Hittite rulers.

\section{Acknowledgments}

The Kinet Höyük excavations were carried out with the permission and encouragement of the Turkish Ministry of Culture and
Tourism; institutional backing from Bilkent University; and funding from the Institute for Aegean Prehistory, the Tarbell Family Foundation, British Petroleum-Turkey, the National Geographic Society, Bilkent University, and other academic institutions. Site supervisors in the West Slope Late Bronze operations were Toni M. Cross (1994-97), and Charles Gates (1998-99; 2005-07); in the Area K Middle Bronze operations: Anna Vivante (1995), Çağatay Karabulut (1998-99), Emre Şerifoğlu (1999), Ayşe Tuğcu (2002-04), Ekin Kozal (2003-04), and Adam Maskevich (2005). Architects Fabien Sanz-Pascual, Benni Claaz-Coockson, Özgecan Yarma, and Klaus Karius; illustrators Neslihan Yllmaz, Fuat Yllmaz, and Serkan Demir; object photographer Tuğrul Çakar; and conservator Franca Cole also collaborated their efforts to the project and to the figures illustrated here. I am grateful for this occasion to express my warmest thanks to these institutions and individuals for their generous participation; and to my student Erkan Akbulut for discussions about the Hittite and Neo-Hittite states. \& 


\section{Notes}

1. According to soundings under its floors, the Period 16 fortress was preceded by one earlier MB II version, and by MB I walling of domestic type and different orientation (Gates 2010:304-8). Both MB II structures were destroyed by earthquake. The Period 16 building was sealed by up to $1.2 \mathrm{~m}$ of sterile, water-laid soil with occasional shells; radiocarbon dates from the base and top suggest it was deposited in one episode (T. Beach, personal communication, 2005). This eastern part of the mound then stayed unoccupied until the Hellenistic period (terracing) and Middle Ages (residential buildings).

2. The MC III-LC I imports were all found in the Period 16 building's Phase 2 (its second and final phase): two Red-on-Black, five BaseRing I, two Monochrome and three Bichrome fragments (E. Kozal, personal communication, 2009).

3. The tight chronological sequence from Period 16 to the earliest Hittite level, Period 15, is indicated by a further three sherds of the shortlived Cypriot Bichrome ware, exclusive at Kinet Höyük to Periods 16 and 15; and by radiocarbon dates in the mid-sixteenth to midfifteenth centuries (Gates 2005: 298).

4. Forlanini (2001: 553-7) relates Puduhepa's visit to Izziya [KUB 56.15] with Kinet Höyük, and approves earlier proposals for Zise and Sissu. The Issos-Sissu-Zise equation was especially developed by Bing (1985 [1993]: 102-9), although others refuse to associate Issos with Sissu/Siz$z u$ on historical and numismatic grounds (e.g. Casabonne 1997: 3841). For a nineteenth-century identification, see Barker 1853: 21-2.

5. For pre-publication photos and comments, see http://www.utoronto.ca/tap/.

\section{References}

Archi, A., and F. Venturi. 2012. Hittites at Tell Afis (Syria). Orientalia 81.1:1-55.

Barker, W. B. 1853. Lares and Penates: or, Cilicia and its Governors. London: Ingram, Cooke.

Beach, T. P. and S. Luzzadder-Beach. 2008. Geoarchaeology and Aggradation around Kinet Höyük, an Archaeological Mound in the Eastern Mediterranean, Turkey. Geomorphology 101:416-28 (doi: 10.1016/j.geomorph.2007.04.025).

Bing, J. D. 1985 [1993]. Sissu/Issus, and Phoenicians in Cilicia. Ameri- can Journal of Ancient History 10:97-123.

Casabonne, O. 1997. Notes ciliciennes. Anatolia Antiqua 5:35-43.

D’Alfonzo, L. and A. E. Killebrew. 2011. A New Anatolian Hieroglyphic Seal Impression from Dağllbaz Höyük, Bay of İskenderun, Turkey. Near Eastern Archaeology 74.2:113-5.

Dinçol, A. M., B. Dinçol, and A. Özten. "Two New Inscribed Storm-God Stelae from Arsuz (Iskenderun) and the Base from Demirköprü (Jisr el-Hadid IV)." Paper presented at Across the Border: Late Bronze-Iron Age Relations between Syria and Anatolia, sponsored by Koç University Research Center for Anatolian Civilizations. Istanbul, Turkey, 1 June 2010.

Forlanini, M. 2001. Quelques notes sur la géographie historique de la Cilicie. Pp. 553-63 in La Cilicie: Espaces et pouvoirs locaux $\left(2^{e}\right.$ millénaire av. J.-C. - $4^{e}$ siècle ap. J.-C.), ed. Ė. Jean, A. M. Dinçol, and S. Durugönül. Istanbul: De Boccard.

Gates, M.-H. 2005. Dating the Hittite Levels at Kinet Höyük: A Revised Chronology. Pp. 293-309 in Structuring and Dating in Hittite Archaeology. Byzas 4, ed. D. P. Mielke, U.-D. Schoop, and J. Seeher. Istanbul: Ege.

2010. 2008 Season at Kinet Höyük (Yeşil-Dörtyol, Hatay). Kazı Sonuçları Toplantısı 31.3:303-20.

— 2011. 2009 Season at Kinet Höyük (Yeşil-Dörtyol, Hatay). Kazı Sonuçları Toplantısı 32.3:182-95.

Knapp, A. B. 2013. The Archaeology of Cyprus from Earliest Prehistory through the Bronze Age. New York: Cambridge University Press.

Muhly, J. D. 2005. Review of L. Steel, Cyprus before History. From the Earliest Settlers to the End of the Bronze Age (London: Duckworth, 2004). In Bryn Mawr Classical Review 2005.09.83 (http://bmcr. brynmawr.edu/2005/2005-09-83.html).

Schoop, U.-D. 2003. Pottery Traditions of the Later Hittite Empire. Problems of Definition. Pp. 167-78 in Identifying Changes: The Transition from Bronze to Iron Ages in Anatolia and its Neighbouring Regions, ed. B. Fischer, H. Genz, Ė. Jean, and K. Köroğlu. Istanbul: Ege.

- 2011. Hittite Pottery: A Summary. Pp. 241-73 in Insights into Hittite History and Archaeology. Colloquia Antiqua 2, ed. H. Genz and D. P. Mielke. Leuven: Peeters.

\section{ABOUT THE AUTHOR}

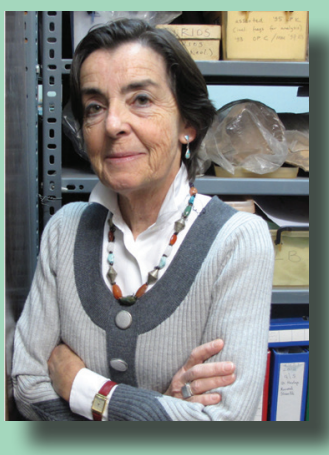

Marie-Henriette Gates has been Associate Professor in the Department of Archaeology at Bilkent University (Ankara, Turkey) since 1990. She specializes in the eastern Mediterranean and Anatolia during the Bronze Age, and directed the excavations at Kinet Höyük, near Iskenderun, from 1992 to 2012. Recent publications include "Southern and Southeastern Anatolia in the Late Bronze Age" in The Oxford Handbook of Ancient Anatolia, edited by S. R. Steadman and G. McMahon (2011). 